\title{
Utilization of Under-Utilized Fruits through Value Addition in Kandi Areas of Jammu Region
}

\author{
Neeraj Gupta*, Meenakshi Trilokia, Monika Sood, Julie Dogra and Jagmohan Singh
}

Division of Food Science and Technology, SKUAST-J, FOA, Chatha, J\&K 180009, India

*Corresponding author

\begin{tabular}{|l|}
\hline Ke y w o r d s \\
Underutilized fruits, \\
Value added \\
products, Nutrition, \\
Processing
\end{tabular}

A B S T R A C T

\begin{abstract}
India is home of world's most useful plants thriving in her diverse agro-ecological zones and altitudes. The varying weather conditions of this country provide suitable environment for growing variety of fruits. Nutritionists recommend that fruits must form an important constituent of the daily diet. Different fruits' colour, varied aroma and taste make them palatable and freshen over mind and body. The importance of fruits lies not only in its nutritive value, but also in the fact that it can be consumed raw and at any time of the day. Utilization of fruits in India depends on its overall production and consumption by individuals and food industries. On the basis of these criteria, it appeared that even the most conventional fruits are under-utilized. These fruits are available in abundance and also in different seasons. This has resulted in limited scope for expansion of other minor fruits, though they are nutritious, and are the main source of livelihood for the poor. Most of the underutilized fruits of the tropics are often available only in the local markets and are practically unknown in the other parts. A large number of these fruits can grow under adverse conditions and are also known for their therapeutic and nutritive value and can satisfy the demands of the health-conscious consumers. However, some of these fruits are not acceptable in the market in fresh form due to their acidic nature and astringent taste. Hence, there is a need to less-known/under-utilized fruit species which have the potential for commercial exploitation are yet to be utilized to their potential. This, to some extent, can be achieved through developing suitable processing and marketing strategies for these underutilized fruits.
\end{abstract}

\section{Introduction}

In general, fruits are rich source of vitamins and minerals. Use of various kind of seasonal fruits helps in keeping human beings healthy and hearty by fulfilling their various requirements. However, there are a number of underutilized fruits which have great medicinal values. Research on these fruit plants regarding their use in ailment of mankind will prove very fruitful in the times to come.

Developing countries are being encouraged to diversify their food exports by developing new products and adding more value to existing products. Value addition and diversifying food exports depends not only on changing production and processing systems, but also on linking into appropriate marketing 
networks. A value chain perspective is used to identify various routes by which the value of food exports can be increased. Fruits are amongst the first food items known consumed pre-historically by human beings. Fruits whether fresh, dried or processed have always formed a part of the staple diet of human beings (Wani et al., 2013). Fruits are undoubtedly very important for nutritional security with high potential of value addition and foreign exchange earnings.

Tropical fruits which are at present underutilized, have an important role to play in satisfying the demands for nutritious, delicately flavoured and attractive natural foods of high therapeutic value (Ravani and Joshi, 2014). Less popular underutilized fruits have been traditionally consumed as staple food and also for medicinal purposes. The fruits like bael, aonla, phalsa, karonda, custard apple, ber, lasoora, jackfruit etc. are of great importance due to their medicinal properties. Only a small quantity of these fruits is used in some pharmaceutical industries. These fruits are the main source of dietary fibre for poor and thus play an important role in overcoming the problem of malnutrition (Gajanana et al., 2010). There is an earnest need to concentrate on research efforts in diversification and popularization of such underutilized fruit crops. This can be achieved through developing suitable processing and marketing strategies for these underutilized fruits by processing them into various products as explained in the paper.

\section{Processing}

Processing is the best way of utilizing surplus production of fruits during seasonal gluts.

Advantages of processing:

Helps in converting perishable fruits in to durable form
Fruits, which are very difficult to eat out of hand can be processed in to a range of highly acceptable fruit product.

Helps in reducing wastage

Value addition

There is great scope of food processing and value addition to the underutilized fruits into various products like jam, jelly, preserve, squash, candy, pickle, dried products, etc.

\section{Aonla}

The fruit is highly nutritious and rich source of pectin and polyphenols apart from ascorbic acid. The storage of Aonla depends on maturity at harvest. The fruit keeps well in cool chamber for 17-18 days as compared to 8-9 days at ambient temperature. It belongs to family Euphorbiaceae and is scientifically identifies as Emblica Officinalis. Aonla fruits are sour and tangy and popularly made into juices, jams and pie-fillings for centuries. Aonla fruits are well known for their medicinal properties. Aonla fruits are used in traditional Indian systems of medicines, like ayurvedic and unani for treating ailments like common cold, gastric troubles, chronic diarrhea, dysentery, headache, constipation, enlarged liver, diabetics, bronchitis, jaundice and fever etc. (Chadha, 2003; Agarwal and Chopra, 2004). It is an important natural capsule of ascorbic acid that contains $600 \mathrm{mg}$ vitamin $\mathrm{C} / 100 \mathrm{~g}$ of pulp. It has also other essential mineral nutrients like calcium, phosphorus, iron and vitamins such as thiamine, riboflavin, niacin etc. (Boora and Bons, 2015). The fruits however have excellent nutritive and therapeutic value, thus having great potentiality for processing into value added products.

Due to its highly acidic and astringent nature the fruit in fresh form or as a table fruit is not 
popular. It is also very important ingredient in the chyavanprash, and a constituent of triphala powder (Boora and Bons, 2015). However, aonla fruits are processed in to a number of food products like preserve, candy, jam, toffee, pickle, sauce, squash, juice, RTS beverage, cider, shreds, dried powder, ladoo etc. (Tondan et al., 2003; Jain et al., 2006; Sagar and Kumar, 2006; Goyal et al., 2008; Bhattacherjee et al., 2011; Pandita et al., 2017).

\section{Karonda}

Karonda (Carrisa carandus linn) is a native plant of India belonging to family Apocynaceae and popularly known as Christs thorn. In India, it is grown on a limited scale in Rajasthan, Gujarat, Bihar, West Bengal and Uttar Pradesh. It is also grown in Sri Lanka lowland rain forests. Karonda is an indigenous protective fruit held in high esteem in Indian dietary.

It is one of the richest source of iron and contains a fair amount of vitamin $\mathrm{C}$ and, therefore, very useful for curing of anaemia and has anti-ascorbutic properties. Enthomedically, fruits are used as astringent, antiasorbutic and as a remedy for biliousness (Jadhav et al., 2004). Usually, the dry fruits contain 264 calories, 2.3 per cent protein, 2.8 per cent minerals, 9.6 per cent fats, 67.1 per cent carbohydrates and 39.1 per cent iron. It is widely used for medicinal purposes by tribals throughout India and popular in various indigenous system of medicine like ayurveda, unani and homoeopathy (Wani et al., 2013). Karonda fruit is rich in iron and contains a fair amount of vitamin C (Boora and Bons, 2015) besides being a good appetizer. Ripe karonda fruits contain high amount of pectin. Therefore, it is also used in making jelly, jam, squash, syrup, tarts and chutney which are of great demand in international market (Wani et al., 2013).

\section{Phalsa}

Grewia Subinequalis (Phalsa) belongs to Tiliaceae family and native to India. Fruits of phalsa are acidic, good source of vitamin A, ascorbic acid and also rich in various other nutrients. Being highly perishable, the fruit must be utilized within 24 hours after picking.

The popularity of phalsa fruit is due to its attractive colour ranging from crimson red to dark purple and its pleasing taste. The juice when extracted gives a deep crimson red to dark purple colour and is very popular. It is rated very high in indigenous system of medicine. The juice is extremely refreshing and is considered to have a cooling effect especially in hot summer. Fruits contain 50-60 per cent juice and edible part of the fruits varies from 69-93 per cent. Generally, its fruits are consumed fresh (Boora and Bons, 2015).

The fruit is astringent and stomachic. It has been reported that when unripe, phalsa fruit alleviates inflammation and is administered respiratory, cardiac and blood disorders, as well as in fever reduction (Singh et al., 2009). In addition, fruits are used for making excellent juice, squash, syrup and crush having cooling effect on the body (Boora and Bons, 2015; Pangotra et al., 2018).

\section{Bael}

Aegle marmelos (Bael) is an important indigenous fruit of India and belongs to Rutaceae family. It is a useful medicinal fruit known to Indian population since time immemorial and has also religious value in Hindu dharma for Shiva's devotees (Boora and Bons, 2015). Bael fruit is a sub-tropical, deciduous tree and fruit is globuse with grey or yellowish hard woody shell. Inside this, there is soft yellow or orange coloured mucilaginous pulp with numerous seed. 
Flow chart of Aonla jam

Washing
$\downarrow$
Boiling
$\downarrow$
Segment
$\downarrow$
Pulp
$\downarrow$
Addition of sugar into pulp (1:1)
$\downarrow$
Heating
$\downarrow$
Aonla jam (end point $68^{\circ}$ brix)

\title{
Flow chart of aonla ladoo
}

\author{
Aonla fruits \\ Sorting \& Grading \\ $\downarrow$ \\ Washing \\ $\downarrow$ \\ Boiling \\ $\downarrow$ \\ Separation of seeds \\ Making of aonla paste \\ $\downarrow$ \\ Addition of Sugar/ Raw sugar \\ Judging of end point (TSS $70^{\circ}$ Brix)

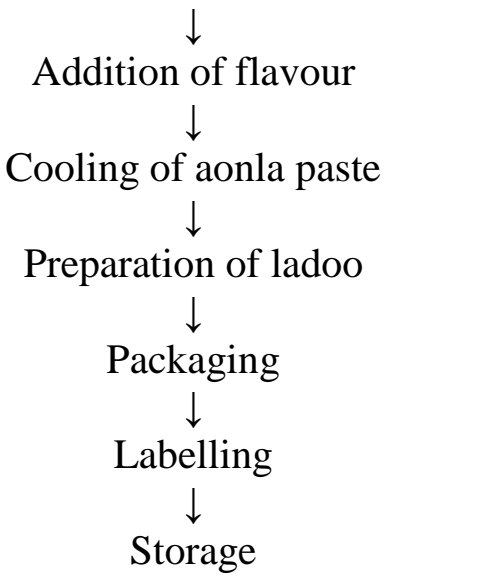




\section{Flow chart of Bael squash}

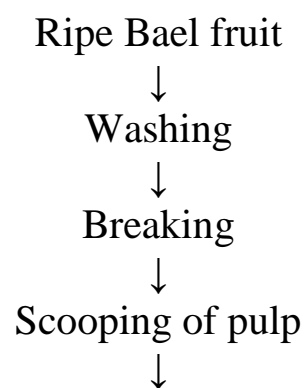

Addition of water into pulp (1:1)

Kneading and heating at $70^{\circ} \mathrm{C}$ for 1 minute

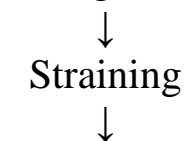

Analysis of TSS (per cent) and acidity (per cent) in bael fruit pulp
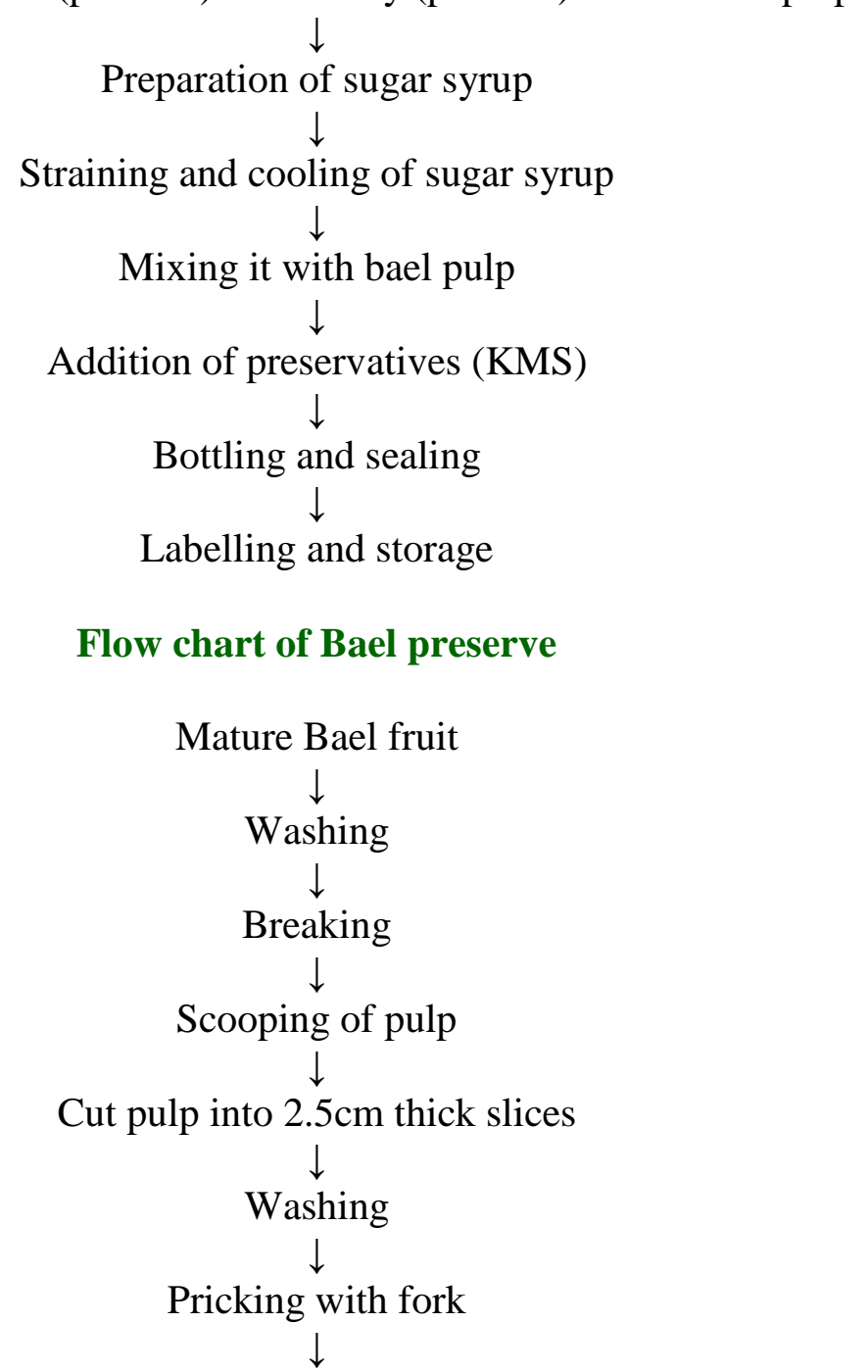


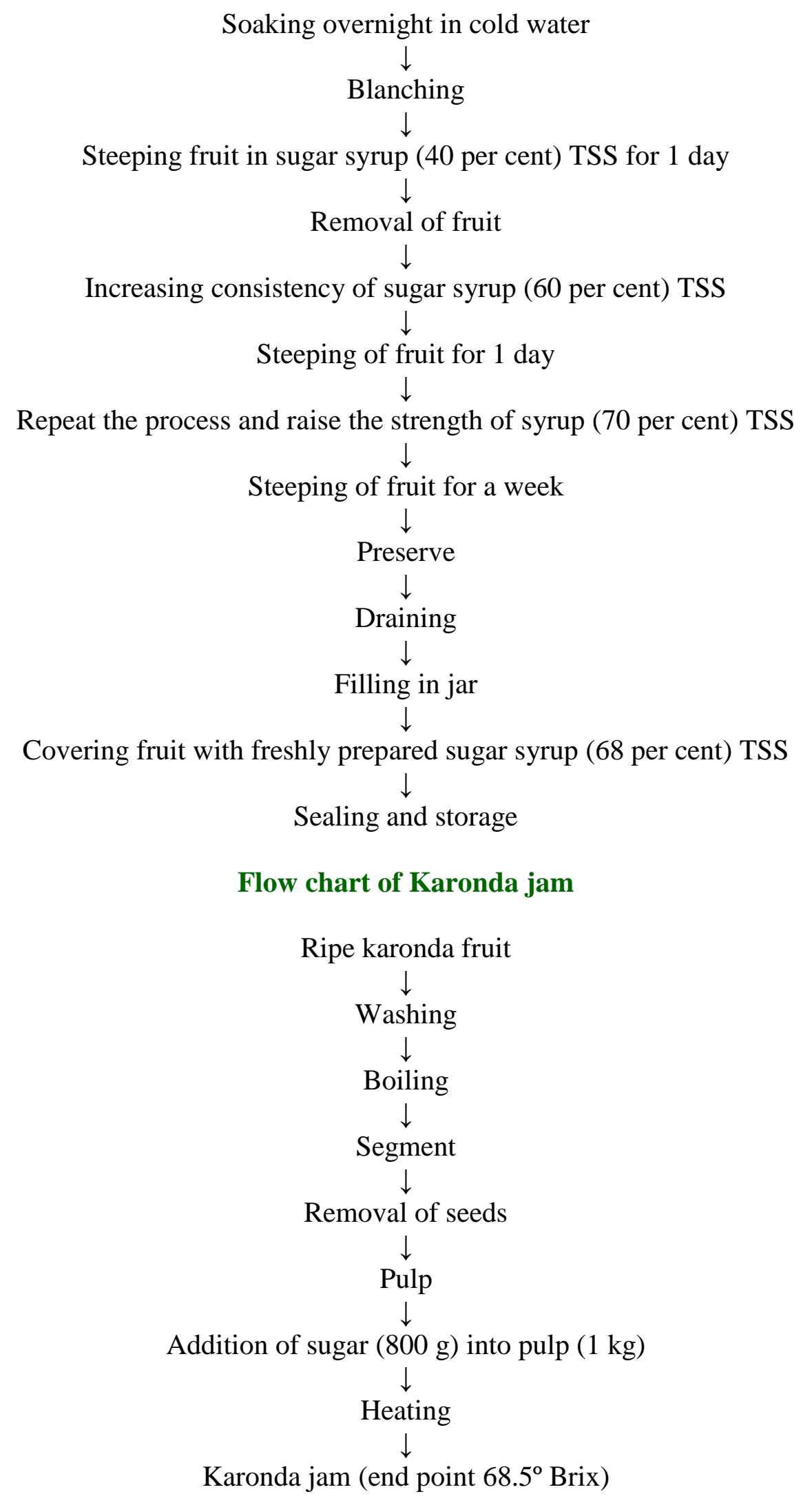




\title{
Flow chart of karonda squash
}

\author{
Ripe karonda fruit \\ $\downarrow$ \\ Washing \\ $\downarrow$ \\ Extraction of pulp \\ $\downarrow$ \\ Removal of seeds \\ $\downarrow$ \\ Preparation of sugar syrup \\ $\downarrow$ \\ Straining and cooling of sugar syrup \\ $\downarrow$ \\ Mixing it with karonda pulp \\ Addition of preservatives \\ $\downarrow$ \\ Bottling and sealing \\ $\downarrow$ \\ Labelling and storage
}

\section{Flow chart of custard apple milk shake}

Mature ripe fruit

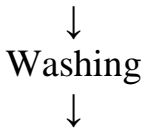

Cutting into two halves

Scooping of pulp

$\downarrow$

Sieving

$\downarrow$

Removal of seeds

$\downarrow$

Addition of jaggery into pulp

$\downarrow$

Addition of milk into pulp (1:1)

$\downarrow$
Mixing
$\downarrow$
Addition of vanilla ess
$\downarrow$
Mixing
$\downarrow$
Cooling
$\downarrow$
Ready to serve


Flow chart of phalsa squash

Ripe Phalsa fruit
$\downarrow$
Washing
$\downarrow$
Extraction of pulp
$\downarrow$
Removal of seeds
$\downarrow$
Preparation of sugar syrup
$\downarrow$
Straining and cooling of sugar syrup
$\downarrow$
Mixing it with Phalsa pulp
$\downarrow$
Addition of preservatives
$\downarrow$
Bottling and sealing
$\downarrow$
Labelling and storage
Addition of water and sugar in to pulp
$\downarrow$
Cooling/addition of ice cubes
$\downarrow$
Ready to serve
Remort of phalsa juice
Ripe Phalsa fruit
$\downarrow$
Washing
$\downarrow$
Extraction of pulp
$\downarrow$
A

Flow chart of jackfruit squash

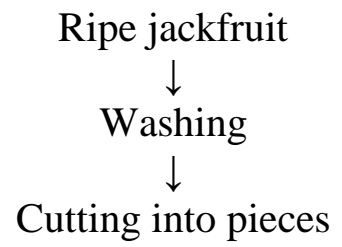

$\downarrow$ 


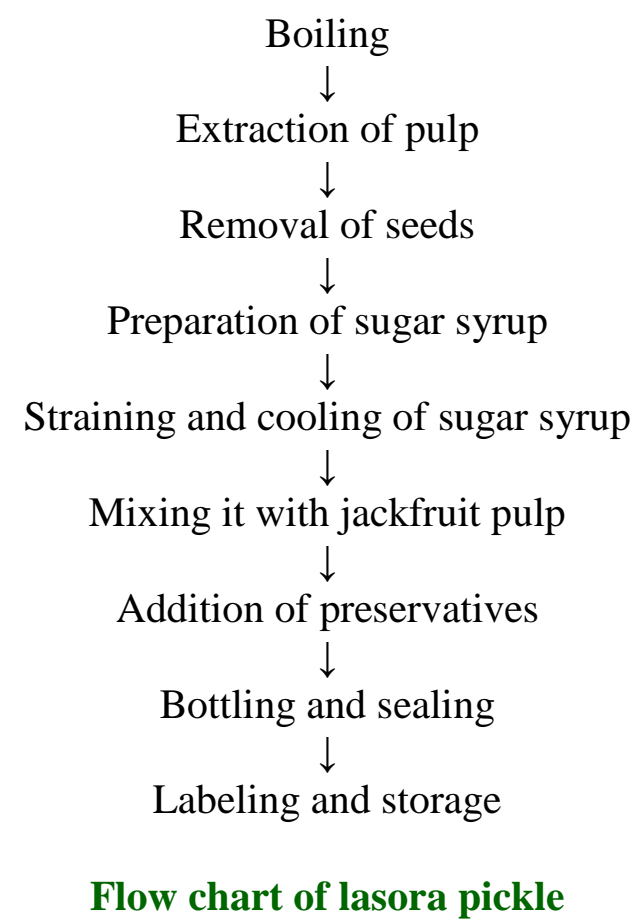

Wash the lasora fruit with water

Break the fruit into two pieces and remove the stone

$\downarrow$

Heat mustard oil in pan, add fenugreek seed, fry till brown and then add lasora fruit and fry

Add spices like thyme powder, red chilli powder, turmeric powder and salt to the mixture cook for 3-5 minutes

Put the cool mixtures into clay pot for fermentation

Heat mustard oil in pan, cool and put into the clay pot over the mixture and kerp in sunlight for fermentation

\section{Flow chart of ber pickle}

Matured green fruits

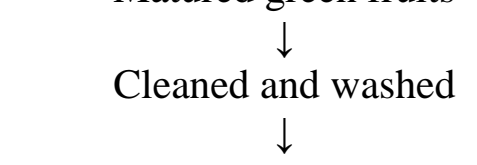

Removed the flower end of fruits

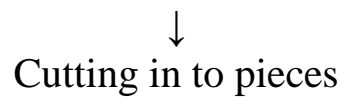

Cutting in to pieces

Added salt 


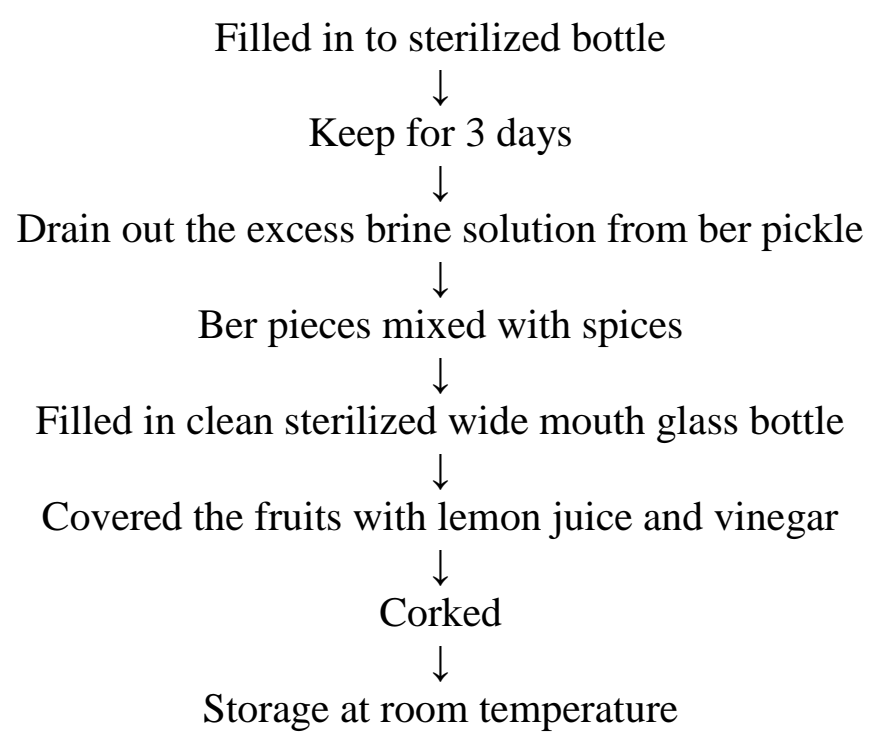

It has numerous seeds, which are densely covered with fibrous hairs and are embedded in a thick, gluey aromatic pulp (Kaushik et al., 2002). Gehlot and Dhawan (2005) reported about all parts of the trees viz., root, bark, leaves, flowers or fruits are used for curing one or other human ailments. The roots are sweet, astringent, bitter and febrifuge. They are useful in curing dyspepsia, dysentery, diarrhea, vitiated condition of vata, vomiting, cardio palmus, stomach algia, intermittent fever, seminal weakness, swelling, uropathy and gastric irritability in infants. Fruit of bael are very nutritious and contains $61.5 \mathrm{~g}$ of water, $1.8 \mathrm{~g}$ of protein, 1.7 $\mathrm{g}$ of minerals, $31.8 \mathrm{~g}$ of carbohydrates and $1.19 \mathrm{mg}$ of riboflavin $/ 100 \mathrm{~g}$ edible portion. According to Gopalan et al., (1978), $100 \mathrm{~g}$ of edible portion of bael contains several important ingredients including protein, fat, mineral, carbohydrates and vitamins. No other fruit has as high content of riboflavin as bael fruit (Singh et al., 2009). Bael has got its medicinal property and is much used in India as a liver and cardiac tonic and when unripe as a mean of halting diarrhea and dysentery and for effective treatment for hiccough, sore throat and diseases of the gums. Bael is used in the preparation of chutneys and for making jelly and jam (Srivastava et al., 2014).

\section{Custard apple}

Annona Squamosa L. (custard apple) is one of the most delicious fruit plants of tropical and sub-tropical areas and belongs to Annonaceae family. In India, the fruits are eaten mainly by the lower and medium class people (Singh et al., 2009). Custard apple is harvested in several installments, but the best harvesting stage is when the firm fruit begins to develop colour. It is generally picked when it becomes creamy yellow between the segments and begins to crack slightly. The fruit has the tendency to burst open if kept on the tree for a long time. Custard apple is highly perishable and cannot be stored for long time. The ripe fruits are rich in sugar. Its pulp contains about 13 per cent moisture, $0.8-1.5$ per cent and 14.5 per cent sugars, 0.3 per cent fat, 1.0 per cent iron and 0.7 per cent mineral matter. It is quite rich in calcium (0.02 per cent), phosphorus (0.04 per cent) and iron (1.0 per cent). The fruit is very sweet and delicious hence is used for table purpose. When fully ripe, it is soft to touch and easily pulled out. The flesh may be scooped from the skin and eaten as is or served with light cream and a springing of sugar. Custard apple can be made into shakes or smoothes or even into natural ice creams (Vishnupriya and Dhandapani, 
2015). Often it is pressed through sieve and added to milk shakes, custards or ice-creams. A delicious sauce for cake and puddings can be made by blending the seeded flesh with mashed banana and a little cream (Singh et al., 2009).

\section{Jack fruit}

Artocarpus heterophyllus (Jackfruit) belongs to Moraceae family native to south India. Jackfruit is absolutely a tropical fruit recognized for its unique shape and size (Longanathan et al., 2017). Jackfruit (Kathal) is an integral part of common Indian diet and is freely available in Indian and adjoining continents, its medicinal properties are also mentioned in Ayurveda. The poor people of jack fruit growing area, used to eat this fruit instead of rice, for one of the daily meals. Hence, jack fruit is called 'poor man's food'. People consumed it mostly as a fruit when ripe but also as a vegetable in the unripe stage. Jack fruit significantly contributes to the nutrition of the people of this country as source of vitamins, minerals and calories. Both tender and ripe fruits as well as the seeds are rich in minerals and vitamins. It is grown and sold in the market almost whole the year in the country. However, the fruit is perishable and cannot be stored for long time because of its inherent compositional and textural characteristics (Molla et al., 2008). The plant is reported to possess anti-bacterial, anti-inflammatory, anti-diabetic, antioxidant and immuno-modulatory properties (Prakash et al., 2009). The ripe jackfruit consists of yellow flesh, pith and large number of bulbs inside the fruit that has carbohydrates, proteins and minerals in sufficient quantity. The ripe fruit also contains macro-nutrients such as vitamins, minerals and organic acids (Tiwari and Vidhyarthi, 2012). The fruit also used in jam, jelly and chutney preparations. Unripe green fruit employed like a vegetable in the preparation known as 'Kathal sabzi' in some north Indian states and 'Sayar nangka' in Indonesia (Loganathan et al., 2017)

\section{Lasoora}

Cordia myxa L. locally known as Gonda, Lasora or lehsua belongs to Boraginaceae family. It grows throughout India except in high hills and temperate climate. It is a perennial, medium sized tree with crooked stem. It bears small sized fruits in bunches, used in traditional vegetable and pickles.

Being a multipurpose plant, it has long been associated with health, nutrition and other diversified uses in curing certain human ailments (Chandra and Pareek, 1992). Fruits are considered as one of richest natural sources of antioxidants i.e. carotenoids, ascorbic acid, phenols etc. Fruits are important sources of minerals, fiber and vitamins, which provides essential nutrients for the human health (Mala, 2009). The most important nutrients present in plants are carbohydrates, such as the starch and free sugars, oils, proteins, minerals, ascorbic acid, and the antioxidant phenols, such as chlorogenic acid and its polymers (Spiller, 2001). Immature green fruits are used as vegetable and pickles. Sometime fruits are dehydrated after blanching for used as vegetable during off season (Singh, 2001).

Minor fruits are the future for horticulture of $21^{\text {st }}$ century as this offer a variety of potential benefits in profitability, productivity, sustainability, crop quality, food safety, environmental protection and rural economic development. A large proportion of rural population depends on locally available fruits to meet their dietary requirements. These fruit crops have their own history of consumption, local people are well aware of their nutritional and medicinal properties. Most of them can be grown even in wastelands without much care. Therefore, it is worthwhile to look into 
the organized cultivation and improvement of under-utilized crops like aonla, bael, karonda, phalsa, jackfruit, custard apple and lasora so that their utilization can be maximized and variety of value added products can also be prepared from them as explained above.

\section{Acknowledgement}

The corresponding author is grateful to Department of Science and Technology, New Delhi for providing funds under SERB-DST project.

\section{References}

Agarwal, S. and Chopra, C. S. 2004. Studies on changes in ascorbic acid and total phenols in making aonla products. Beverage and Food World, 31 (5): 3233.

Bhattacharjee, A. K., Tandon, D. K., Dikshit, A. and Kumar, S. 2011. Effect of pasteurization temperature on quality of aonla juice during storage. Journal of Food Science and Technology, 48 (3): 269-273.

Boora, R. S. and Bons, H. K. 2015.The minor fruits-health treasure. Kisan world, 42 (11): pp: 32-33.

Chadha, K. L. 2003. Handbook of Horticulture. ICAR Publication. New Delhi.

Chandra, A. and Pareek, C. S. 1992. Lasoda (Cordia myxa L.) potential fruit crop in Jaisalmer district of western Rajasthan. Agricultural Science Digest, 12 (1):1112.

Gajanana, T. M., Gowda, I. N. D. and Reddy, B. M. C. 2010. Exploring market potential and developing linkages-A case of underutilized fruit products in India. Agricultural economics research review, 23: 437-443.

Gehlot, R. and Dhawan, S. S. 2005. Bael: A valuable tree. Food and Pack, 5 (7): 2829.
Gopalan, C., Rama Sastri, B. V. and Balasubramanian, S. C 1978. Nutritive value of Indian foods. National Institute of Nutrition, ICMR, Hyderabad, India.

Goyal, R. T., Patil, R.T., Kingsly A. R. P., Walia, H. and Kumar, P. 2008. Status of post harvest technology of aonla in India- A Review. American Journal of Food Technology, 3 (1): 13-23.

Jadhav, S. B., Joshi, G. D. and Garande, V. K. 2004. Studies on preparation and storage of karonda (Carissa carandas Linn.) fruit products. Beverage Food World, 31 (5): 46-47.

Jain, V., Singh, S. and Singh, A. K. 2006. Screening of aonla cultivars for making squash. Indian Journal of Arid horticulture, 1(1): 44-46.

Kaushik, R. A., Yamdagni, R. and Sharma, J. R. 2002. Changes in quality parameters during processing and storage of processed bael fruit. Indian Food Packer, Jan-Feb.: 71-76.

Loganathan, P., Rajadurai, A. and Malliga, C. 2017. Jackfruit: Its medicinal uses and benefits. Kisan World, 44 (6): 7-9.

Mala, R. 2009. Nutrient content of important fruit trees from arid zone of Rajasthan. Journal of Horticulture, 1 (7): 103-108.

Molla, M. M., Nasrin, T. A. A., Islam, M. N. and Bhiujan, M. A. 2008. Preparation and packaging of jackfruit chips. International Journal of Sustainable Crop Production, 3 (6): 41-47.

Pandita, N., Gupta, N., Bhat, A. and Kaul, R. K. 2017. Performance evaluation of flavored ladoo prepared from different cultivars of aonla (Emblica officinalis Gaertn). Biocsan, 12 (1): 101-105.

Pangotra, B. B., Gupta, N. and Sharma, A. 2018. Development of freshly prepared phalsa-pear blended beverage. International Journal of Current Microbiology and Applied Sciences, 7 (2): 2870-2876. 
Prakash, O., Kumar, R., Mishra, A. and Gupta, R. 2009. Artocarpus heterophyllus: An overview. PHCOG Rev: Review Article, 3 (6): 353-358.

Ravani, A. and Joshi, D.C. 2014. Processing for value addition of underutilized fruit crops. Trends in Post-Harvest Technology, 2 (2):15-21.

Sagar V. R. and Kumar, R. 2006. Preparation and storage study of ready to eat dehydrated gooseberry shreds. Journal of Food Science and Technology, 43 (4): 349-352.

Singh, I. S. 2001. Minor fruits and their uses. Indian Journal of Horticulture, 58: 178182.

Spiller, G. A. 2001. Dietary fiber in prevention and treatment of disease. In: Spiller GA (ed) CRC handbook of dietary fiber in human nutrition. CRC Press LLC, Washington: 363-431.

Srivastava, S., Neerubala, V., Kumari, N. and Singh, N. 2014. Development of flavoured preserved products using bael. International Journal of Food Science and Agricultural Sciences, 3 (1): 80-86.

Tiwari, A. K. and Vidhyarthi, A. S. 2012. Jackfruit Jam: Preparation, nutritive values and storage stability. PHARMBIT: 1-2.

Tondan, D. K., Yadav, R. C., Sood, S., Kumar, S. and Dikshit, A. 2003. Effects of blanching and lye peeling on the quality of aonla candy. Indian Food Packer, 57 (6): 147-152.

Vishnupriya, M. S. and Dhandapani, C. 2015. Medicinal uses and natural values of custard apple. Kisan World, 42 (11): 3739.

Wani, R. A., Prasad, V. M., Hakeem, S. A., Sheema, S., Angchuk, P. and Dixit. A. 2013. Shelf life of karonda (Carrisa carandus L.) jams under ambient temperature. African Journal of Agricultural Research, 8 (21): 24472449.

\section{How to cite this article:}

Neeraj Gupta, Meenakshi Trilokia, Monika Sood, Julie Dogra and Jagmohan Singh. 2018. Utilization of Under-Utilized Fruits through Value Addition in Kandi Areas of Jammu Region. Int.J.Curr.Microbiol.App.Sci. 7(05): 1965-1977. doi: https://doi.org/10.20546/ijcmas.2018.705.231 